\title{
Hydraulic and Groundwater Chemical Parameters of the Aquifer in Malakasari, Bandung
}

\author{
Jemi S. Ahnaf ${ }^{1, *}$,Zufialdi Zakaria ${ }^{1}$, and Aton Patonah ${ }^{1}$ \\ ${ }^{1}$ Geology Engineering Department, Padjadjaran University, 45363 Sumedang, Indonesia
}

\begin{abstract}
In order to reveal the physical condition of the aquifer, the pumping test using Cooper-Jacob (1946) principle has conducted at well SM5. The observation data of the test then processed to generate various value of hydraulic properties i.e. $3.241 \times 10-4 \mathrm{~cm}^{2} / \mathrm{sec}$ for transmissivity (T), $8.103 \times 10-6 \mathrm{~cm} / \mathrm{sec}$ for conductivity (K), 0.05055 for storativity (S), and 3.852x10-3 $\mathrm{ft}^{-1}$ for specific storage (Ss). These data show that the aquifer composed of unconsolidated sedimentary rocks ranged from coarse sand to silt. In addition, also performed the feasibility test of groundwater by using Multimeter which produces chemical parameter data. The chemical parameter of eight well samples have average values of $6.62,766.25 \mu \mathrm{s} / \mathrm{cm}$ and 376.25 $\mathrm{mg} / \mathrm{L}$ for $\mathrm{pH}$, electric conductivity (EC), and total dissolved solid (TDS) respectively, while physical observation shows no turbidity and odor.
\end{abstract}

\section{Introduction}

\subsection{Research background}

Human needs for fresh water will continue to increase as the population increases, and indirectly causes studies on hydrogeology continue intensively in the future. This not surprising in behalf of water is one of the eminent human needs both for rural and urban communities, specifically it stated in [1] that surface water and groundwater are the main water sources that people used to meet various needs. Thus, it would be useful if groundwater studies were conducted, at least to perceive potential areas for water exploration. Furthermore, [2] reinforced that the need for water by humans is endless, especially clean water that feasible for household uses such as bathing, cooking, even the most crucial is to drink.

This study aimed to determine the physical properties of aquifer and water chemical parameters in Malakasari, it is expected that the results of this research will be a preliminary study for exploration or further research. Meanwhile in the framework of exploration, studying hydrogeological aspects such as aquifer or water chemical parameters are particularly important as it supports the sustainability of the exploration. The aquifer plays an important role in storing and passing water so that it can be assessed its physical properties to know the values of transmissivity $(\mathrm{T})$, conductivity $(\mathrm{K})$, storativity $(\mathrm{S})$, and specific storage (Ss). While water chemical parameters can be used to determine groundwater ground quality before further advance water chemistry analysis, by observing it, parameters such as $\mathrm{pH}$, Electric Conductivity (EC), and Total Dissolved Solid (TDS) are known.

\subsection{Research location and geology condition}

This research located in Malakasari Village, Baleendah district, Bandung Regency, West Java Province. Malakasari has an average air temperature of $24^{\circ} \mathrm{c}-30^{\circ} \mathrm{c}$ and fairly fluctuating rainfall average of $1,856 \mathrm{~mm}$ per year which administratively bordered by Bojong Malaka in the north, Rancamanyar in the west, Baleendah in the south, while the eastern part is bordered by the Citarum river and Andir. Based on the Geological Map of the Garut and Pamuengpuek quadrangle [3], the research area included in the quaternary deposits resulting from volcanic activities, the area included in Qd unit which is a sediment lake with rock composition such as clay, silt, fine-coarse sand, and gravel, generally these rocks are tuffaceous and has young age (Quaternary). Furthermore, in a view of geomorphology, this area classified as highland category that located at altitude of 600-715 msl and belongs to the Bandung basin.

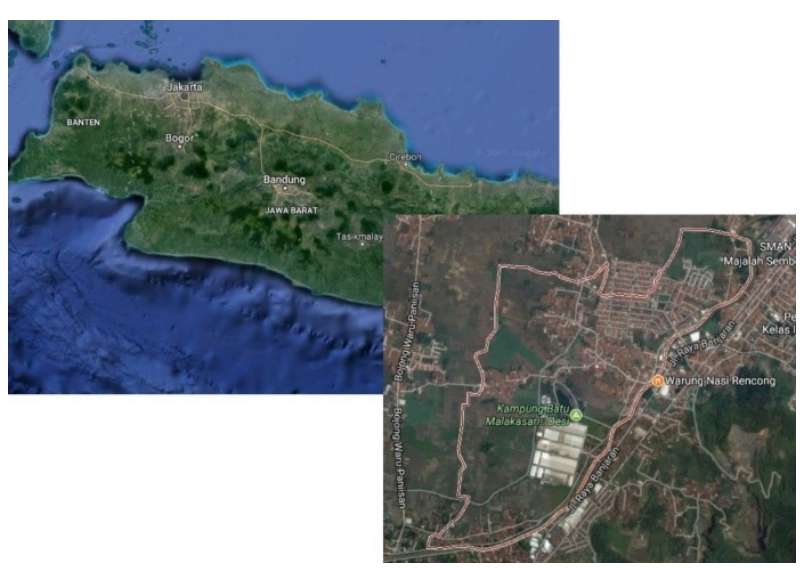

\footnotetext{
* Corresponding author: jemi14001@mail.unpad.ac.id
} 
Fig. 1. Location of research area in Malakasari Village, District Baleendah, Bandung Regency, West Java Province.

Uncoordinated and unscaled, image sourced from Google Map Pro.

\subsection{Aquifer test}

Aquifer is a layer of rock that has a cavity between the granules or cavities due to fractures, where these cavities contain water and are able to drain the water in sufficient quantities [4], according to Halik \& S. (2008) in [5], before groundwater drilling is carried out, a preliminary ground investigation is done to determine the presence of carrier layer (aquifer). In addition, this aquifer investigation can also determine its physical condition by performing an aquifer test.

An aquifer test is a test to forecast aquifer physical condition by determining its hydraulic properties. This test do through pumping test, while pumping test itself is a practical and reliable method of estimating well performance, well yield, the zone of influence of the well and aquifer characteristics (i.e., the aquifer's ability to store and transmit water, aquifer extent, presence of boundary conditions and possible hydraulic connection to surface water). The analysis of the hydraulics of wells for the evaluation of groundwater potentialities by pumping tests falls in the category of groundwater hydrology [6]. Actually, aquifer test could also perform through slug test, but it provide limited information on the hydraulic properties of the aquifer and often produce estimates which are only accurate [7], thus pumping test more common used than the slug test.

\section{Method}

Pumping test by principle of Cooper-Jacob (1946) conducted to acquire hydraulic properties condition of the aquifer at SM5, this pumping conducted with a constant debit (long-term constant rate) by aid of Jet Pump. From this test, the data produced are changes in the drawdown to its elapsed time, these data are then processed using AQTESOLV (an aquifer test program) to generate hydraulic values as well as transmissivity (T), conductivity (K), storativity (S) and specific storage (Ss). In addition, all samples from eight wells analyzed by Multimeter to give picture related to water chemical parameters such as $\mathrm{pH}, \mathrm{EC}$ and TDS, besides the physical parameters of water as temperature, color, and odor were also observed.

\section{Result and discussion}

\subsection{Pumping test}

Pumping test conducted in well SM5, which is a representative of the 8 wells mapped. The well is located on coordinates $\mathrm{S} 07^{\circ} 00^{\prime} 22.77^{\prime \prime}$ and $\mathrm{E} 107^{\circ} 36^{\prime} 30.55^{\prime \prime}$ ' at an elevation of $679 \mathrm{~m}$ above sea level with watertable saturated at $677.60 \mathrm{~m}$, this well also has $3.80 \mathrm{~m}$ in depth and $0.75 \mathrm{~m}$ and $1.1 \mathrm{~m}$ for inner and outer diameter respectyively. Pumping test carried out by draining water out aided by Jet Pump, thus debit of water taken is constant amounted to 0.214 liter $/ \mathrm{s}$ or $0.01284 \mathrm{~m}^{3} / \mathrm{m}$. The test is single-well test, as consequence, drowdown measured in pumped well only and induce observation glued to well SM 5. The data that produced from observation during pumping test then processed by AQTESOLV using the Cooper-Jacob (1946) principle.

Table 1. Observation data of pumping test from SM 5, displacement is the change in head relative to the static condition (drowdown), displacement $=h(0)-h(t)$, where $h(0)$ is the initial (static) head and $\mathrm{h}(\mathrm{t})$ is the head at time $\mathrm{t}$.

\begin{tabular}{|c|c|c|c|c|c|}
\hline $\begin{array}{c}\text { Time } \\
(\mathbf{m i n})\end{array}$ & $\begin{array}{c}\text { Displac } \\
\text { ement } \\
(\mathbf{m})\end{array}$ & $\begin{array}{c}\text { Time } \\
(\mathbf{m i n})\end{array}$ & $\begin{array}{c}\text { Displac } \\
\text { ement } \\
(\mathbf{m})\end{array}$ & $\begin{array}{c}\text { Time } \\
\mathbf{( m i n )}\end{array}$ & $\begin{array}{c}\text { Displac } \\
\text { ement } \\
(\mathbf{m})\end{array}$ \\
\hline 1 & 0.01 & 14 & 0.12 & 60 & 0.18 \\
\hline 2 & 0.02 & 16 & 0.12 & 70 & 0.20 \\
\hline 3 & 0.04 & 18 & 0.13 & 80 & 0.22 \\
\hline 4 & 0.07 & 20 & 0.12 & 90 & 0.23 \\
\hline 5 & 0.07 & 25 & 0.13 & 100 & 0.24 \\
\hline 6 & 0.08 & 30 & 0.14 & 110 & 0.25 \\
\hline 7 & 0.09 & 35 & 0.16 & 120 & 0.25 \\
\hline 8 & 0.09 & 40 & 0.16 & 135 & 0.26 \\
\hline 9 & 0.10 & 45 & 0.17 & 150 & 0.26 \\
\hline 10 & 0.10 & 50 & 0.17 & 165 & 0.26 \\
\hline 12 & 0.11 & 55 & 0.18 & 180 & 0.26 \\
\hline
\end{tabular}

Pumping test was conducted non-stop until water level shows steady state (no change displacement within a certain time), this situation occurs when the amount of water pumped equal to the entering water from the aquifer. In this observation, steady state began to occur in minute 135, therefore, in minute 180 the test was stopped and continue to observe recovery well by measuring the rise of water level to its elapsed time. Observation of recovery well done until the water level back to its original state before the well pumped. This state accomplished within a period of 240 minutes, thus recovery time is 60 minutes longer than pumping time, this situation indicates that the amount of debit taken during pumping, i.e. $0.0128 \mathrm{~m}^{3} / \mathrm{m}$ is greater than entering water from aquifer to the well.

The displacement-time plot shows a linear trend that corresponds to the Cooper-Jacob (1946) graph should be, it means the retrieval and processing data of the test are compatible. A derivative $\mathrm{ds} / \mathrm{d}(\log (\mathrm{t}))$-time plot provide a useful diagnostic tool for detecting deviation in the rate of displacement change, for example this plot can help in identification of wellbore storage and aquifer boundaries, unfortunately, other needed data to determine the aquifer boundaries is still lacking, so it could not be determined. But certainly from this derivative plot is known that the largest change displacement occurred in the minute 20 (lowest) to minute 100 (highest), but even then, the average change displacement occur quite negligible at around $0.05 \mathrm{~m}$. 

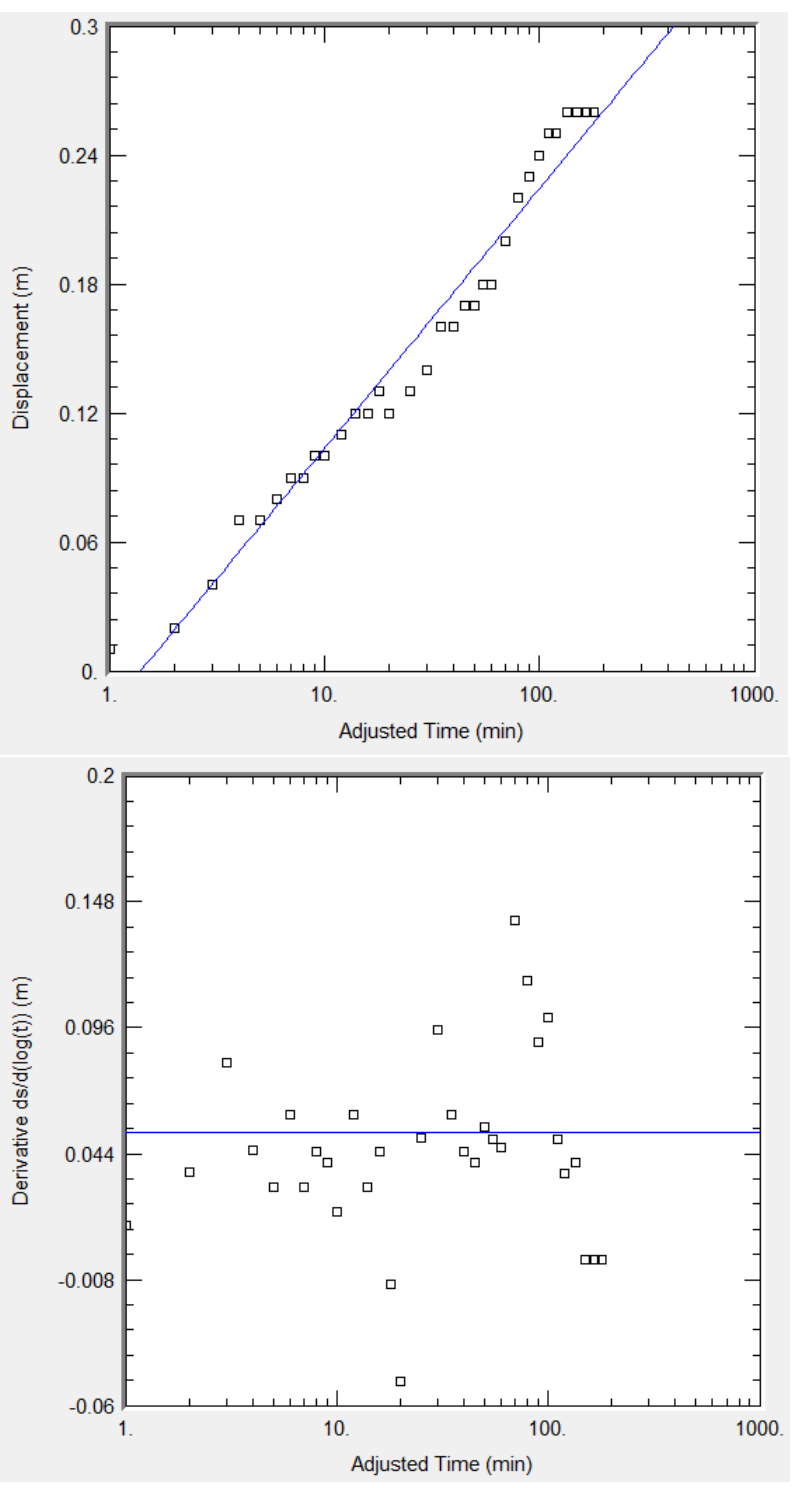

Fig. 2. These graphs are interpretation of the observational data were processed using AQTESOLV, (above) displacement-time plot, and (below) derivative ds $/ \mathrm{d}(\log (\mathrm{t}))$-time plot.

\subsection{Hydraulic properties}

The hydraulic properties determined from this research are transmissivity $(\mathrm{T})$, conductivity $(\mathrm{K})$, storativity $(\mathrm{S})$, and specific storage (Ss), which has a value $3.241 \times 10^{-4}$ $\mathrm{cm}^{2} / \mathrm{sec}, 8.103 \times 10^{-6} \mathrm{~cm} / \mathrm{sec}, 0.05055,3.852 \times 10-3 \mathrm{ft}^{-1}$, respectively. These values then examined to describe the type of material making up the aquifer. In short, transimissivity used to define conductivity which then interpreted to seek the material making up the aquifer based on Domenico \& Schwartz (1990) table [8]. Since the aquifer in the research area possibly sediments have not been litified (Quaternary lake deposit), used unconsolidated sedimentary rocks table to narrow down the possibilities. With the value of hydraulic conductivity $8.103 \times 10-6 \mathrm{~cm} / \mathrm{sec}$, then material making up the aquifer should be unconsolidated coarse-fine sand to silt.

As transmissivity used to define the conductivity value, so does the storativity (S) to specific storage (Ss). The specific storage then interpreted to describe geological material of the aquifer as conductivity did. By value $3.852 \times 10-3 \mathrm{ft}^{-1}$ of specific storage and using Domenico \& Mifflin (1965) table [9], the possibility constituent materials of the aquifer are dominantly plastic clay, this does not correspond to the conductivity that indicates unconsolidated coarse-fine sand to silt for the aquifer.

Table 2. Representative values of hydraulic conductivity for various unconsolidated sedimentary materials (Domenico \& Schwartz, 1990) [8].

\begin{tabular}{|c|c|}
\hline \multicolumn{2}{|c|}{ Unconsolidated sedimentary material } \\
\hline Material & $\begin{array}{c}\text { Hydraulic conductivity } \\
\text { (cm/sec) }\end{array}$ \\
\hline Gravel & $3 \times 10^{-4}$ to $3 \times 10^{-2}$ \\
\hline Coarse sand & $9 \times 10^{-7}$ to $6 \times 10^{-3}$ \\
\hline Medium sand & $9 \times 10^{-7}$ to $5 \times 10^{-4}$ \\
\hline Fine sand & $2 \times 10^{-7}$ to $2 \times 10^{-4}$ \\
\hline Silt, loess & $1 \times 10^{-9}$ to $2 \times 10^{-5}$ \\
\hline Till & $1 \times 10^{-12}$ to $2 \times 10^{-6}$ \\
\hline Clay & $1 \times 10^{-11}$ to $4.7 \times 10^{-9}$ \\
\hline Unweathered marine clay & $8 \times 10^{-13}$ to $2 \times 10^{-9}$ \\
\hline
\end{tabular}

\subsection{Water chemical parameters}

Eight well water samples were taken and tested by using a multimeter to determine its chemical parameters. This test can be used for rough water quality analysis before further analysis related to ion-cation of water, in fact this parameter is only useful as the preliminary data and can not be used as the main data for determining the feasibility of groundwater to be drinking water, consequently it will be discussed in outline.

From the test, the average value for $\mathrm{pH}$ is $6.62, \mathrm{EC}$ is $766.25 \mu \mathrm{s} / \mathrm{cm}$, and TDS is $376.25 \mathrm{mg} / \mathrm{L}$. All samples showed normal $\mathrm{pH}$ and near-acid values for the SM6 and SM8 samples. These values are quite good, because according to World Health Organization (WHO) drinking water standards in Oyem (2014) [10] recommends a pH value above 6.5 to avoid corrosion. The $\mathrm{EC}$ value is usually twice from its TDS, so the interpretation can be represented by TDS. The TDS shows an average value of $376.25 \mathrm{mg} / \mathrm{L}$, WHO in [10] recommends a TDS value of $1000 \mathrm{mg} / \mathrm{L}$, whereas Queensland Health Forensic Scientific Services (QHFSS) recommends a value below $500 \mathrm{mg} / \mathrm{L}$ for taste reason. Thus the WHO recommendation value for TDS does not meet for these samples, but however these samples are complied to TDS standard of QFHSS. In addition, it needs to be analyzed further since these samples are not directly taken from the aquifer.

Table 3. Chemical and physical parameters of water eight well samples. The measuring of physical parameters such as $\mathrm{T}$, turbidity, and odor conducted at the time of sampling. 


\begin{tabular}{|l|l|l|l|l|l|l|}
\hline $\begin{array}{l}\text { Sam } \\
\text { ple }\end{array}$ & $\mathbf{p H}$ & $\begin{array}{l}\text { EC } \\
(\boldsymbol{\mu s} / \mathbf{c m})\end{array}$ & $\begin{array}{l}\text { TDS } \\
(\mathbf{m g} / \mathbf{L})\end{array}$ & $\begin{array}{l}\mathbf{T} \\
\left({ }^{\mathbf{c}} \mathbf{c}\right)\end{array}$ & $\begin{array}{l}\text { Turbi } \\
\mathbf{d i t y}\end{array}$ & $\begin{array}{l}\text { Od } \\
\text { or }\end{array}$ \\
\hline SM1 & 6.6 & 1.070 & 520 & 25 & no & no \\
\hline SM2 & 6.6 & 900 & 470 & 25 & no & no \\
\hline SM3 & 6.8 & 700 & 340 & 26 & no & no \\
\hline SM4 & 6.9 & 830 & 410 & 24 & no & no \\
\hline SM5 & 6.6 & 800 & 390 & 25 & no & no \\
\hline SM6 & 6.5 & 580 & 280 & 25 & no & no \\
\hline SM7 & 6.6 & 780 & 380 & 25 & no & no \\
\hline SM8 & 6.4 & 470 & 220 & 25 & no & no \\
\hline
\end{tabular}

10. H.H. Oyem, I.I. Oyem, D. Ezaweali, Research Journal of Environmental Science, 8, 444-450 (2014).

\section{Conclusion}

Data interpretation of pumping test using AQTESOLV generated various values of hydraulic properties i.e. $3.241 \times 10-4 \mathrm{~cm} 2 / \mathrm{sec}$ for transmissivity (T), 8.103 $\times 10-6$ $\mathrm{cm} / \mathrm{sec}$ for conductivity (K), 0.05055 for storativity (S), and $3.852 \times 10-3 \mathrm{ft}-1$ for specific storage (Ss), hence predicted that the constituent material of the aquifer is in the form of unconsolidated sediments which ranged from coarse-fine sand to silt. Chemical parameter analysis of well samples shows average values of $6.62,766.25 \mu \mathrm{s} / \mathrm{cm}$ and $376.25 \mathrm{mg} / \mathrm{L}$ for $\mathrm{pH} \mathrm{EC}$ and TDS respectively. Thus, according to WHO and QHFSS, groundwater in the Malaksari complied to standard of drinking water, making it possible to further groundwater exploration, but it needs more detailed analysis to other water chemistry such as total hardness, temporary hardness, alkalinity, anioncation content, the content of trace element and so forth.

\section{References}

1. D.A. Enggarwati, A. Susilo, D.D. Wardhana, Physics Student Journal Univ. Brawijaya (2015)

2. Z. Lubis, N.A. Affandy, Jurnal Teknika, 6, 577-588 (2014)

3. M. Alzwar, N. Akbar, S. Bachri, Geological Map of the Garut and Pameungpeuk Quadrangle, Java, Geological Research and Development Centre, Indonesia (1992).

4. R.S. Waspodo, jTEP Jurnal Keteknikan Pertanian, 25, 29-35 (2011)

5. G. Halik, J. Widodo, Media Teknik Sipil, 109-114 (2008)

6. J. Bruin, H.E. Hudson, Report of Investigation, Department of Registration and Education, Illinois, (1961)

7. P.S. Osborne, Ground Water Issue-United State Environmental Protection Agency, (1993)

8. P.A. Domenico, F.W. Schwartz, Physical and Chemical Hydrogeology, John Wiley \& Sons, (1990)

9. P.A. Domenico, M.D. Mifflin, Water Resources Research, 1, 563-576 (1965) 